\title{
Successful Antecedents of Women
}

\section{Entrepreneurs: A Case of Underdeveloped Nation}

\author{
${ }^{1}$ Department of Management, Xidian University, Shanxi, Xian 710071, China, E-mail: drbatoolhira@gmail.com \\ ${ }^{2}$ Department of Sports Sciences, The University of Lahore, New Campus, Defense Road, Lahore, Punjab, Pakistan, E-mail: \\ kalimullah1118@gmail.com
}

\begin{abstract}
:
Women as the emergent economic power influence the shape of the global economy. For the prosperity of the nation, it is important that women should be involved in the job creation activities rather than providing with the job opportunities, as businesses are more time flexible than being an employee especially for women; where they are playing multiple roles at a time. In order to work on the efficiency and efficacy of the entire women, this paper studied the relationship between successful antecedent such as motivation, personality trait, creativity, access to finance, family factors and success of women entrepreneurial endeavors was being assessed. For this purpose data were collected from women entrepreneurs through a purposive sampling technique by using five likert scale questionnaire. Analysis of the study revealed that antecedents plays a positive role in the success of women entrepreneurial endeavors, however family support also appears to have a strong mediation effect on the success of women entrepreneurial endeavors but a negative value of beta indicates that women in underdeveloped society generally are not warmly encouraged by the family to opt for entrepreneurial endeavors. So, there is a need to work on this aspect in order to encourage other female participation in the economic growth.
\end{abstract}

Keywords: entrepreneur, endeavor, motivation, women, success, factors

DOI: 10.1515/erj-2016-0066

\section{Introduction}

Barringer and Ireland (2011) describe an entrepreneur as a creator of new venture who faces uncertainty in many ways. They are individuals who have the capability to force opportunities, gather the needed resourcestime, energy, and money-with actions which are necessary to ensure success (Carter and Evans 2012). Women entrepreneurship had been viewed as a process of innovation regardless of literacy fact with the creation and skill factor (Audretsch, Keilbach, and Lehmann 2006).

Steadily, in the global market women are more active in starting their own businesses. Female contribute one third of the population involved in entrepreneurial activities. Studies in Pakistan shown that there is no effective development strategy for females to participate in business activities that's why they are unable to play a central role as the successful women entrepreneurs (AlMunajjed 2013). Increasing number of women enterprise can facilitate job creation, output growth, tax revenue, increased number of goods and services. Women entrepreneurs are significant for social and economic development (Audretsch, Keilbach, and Lehmann 2006).

Research concluded that a majority of Pakistani women is contributing to household income and raises its standard of living from teaching. The women entrepreneurs are very small in number and there is strong need to study the experience of women entrepreneurs and implement them for other female so that the economy can be better developed. Besides providing them with job opportunities, on of the best ways to make them socially and economically independent in their own areas to each and every women regardless of they are literature or illiterate is via entrepreneurship (Adetu 2014).

Progression of entrepreneurial opportunities is the crucial requisite for Pakistan, most predominantly for women. As per a labor force survey conducted by Ministry of Labor (2012), total labor force in the country rises to 60.3 million but only 59.2 million is employed. Only twenty percent of the employed force is females, which indicates the presence of gender gap in Pakistani labor market. Abdullah (2012) revealed that females are still underutilized yet an important section of the labor market. This indicates "the need of government intentions to introduce targeted programs to enhance chances of female participation in labor market" (Greenhill 2011). 
Bornstein (2012) conclude that, entrepreneurship in developing countries is probably the least studied topic in economic and social research. There is still a need to examine factors which cause women to opt for entrepreneurial endeavors and affect their success in Pakistan. This paper will be useful to find out factors that affect success or failure of women entrepreneurs.

Current paper is structure as that, the first section of the paper describes the facts of women entrepreneur and need for conducting this study. Secondly, paper gives literature support for formulating research framework and related hypothesis. Methodology and discussion will help to draw a final conclusion about the struggle of the paper in bringing useful outcomes for welfare of the Pakistani economy.

\section{Literature Review}

"Women entrepreneurs' percentage is higher in countries having lower per capita income like Angola, Bolivia, and Peru while the same percentage is lower in countries with higher per capita income e. g. Israel, Germany and UK. This explains the difference between push and pulls entrepreneurs" (Alsahlawi 2011) Where push factors are forced toward entrepreneurial endeavors while pull entrepreneurs are attracted toward entrepreneurial endeavors (Charantimath 2005).

In present economic situation the economic empowerment is very important for Pakistan not only for economic development but also for social development (Labor Policy 2013). During past ten years the rate of women participation in economic activities has not been changed they are still less than male counterparts (Gorchels 2012). Study conducted byMakhlouf (2011) that female do not have access to same facilities as male are enjoying especially in terms of access of finance and superior status of male community.

This inferior status of female community restricts their mobility due to the social boundaries like all the public transport offer only limited seats, e. g. only first or second row of seats for women and the rest of the seats in busses and vans for male members of the society. Afza, Hassan, and Rashid (2010) revealed that socio-economic growth is being adverse in Pakistan due to its geo-political crisis which has also affected women entrepreneur in Pakistan along with all other business areas.

Major constraints for women entrepreneurs in Pakistan include gender discrimination, family and social support, not easy access to information, insufficient education and not trusting ones capabilities. Along with all these difficulties, Blanch (2011) concludes that women face challenges of male dominance, dependency upon male counterparts for financial transactions and restrictions imposed by society only on women.

Women entrepreneurs are regarded as social uplifting for family, generating economic growth and causing job creations (Hany 2011). Global trends of women entrepreneurs motivated women in Pakistan to opt for self-employment with a hope to be in charge of their personal lives (Kavanagh, Murphy, and Dwyer 2012). However, in Pakistan the business situation for women emulates two aspects; first one includes social, cultural and religious limitations while other one consists of constitutional, policy and regulations (Richi 2011). Begum (2011) exposed that very limited research is being done in case of problems faced by women entrepreneurs and how they affect working efficiency of women entrepreneurs that may lead concerned authorities to formulate policies to eradicate these problems in order to improve environment where women entrepreneurs may nourish.

\section{Context Analysis about Worse Women Entrepreneurial Situation in Pakistan}

Chitsike (2000) study showed that Pakistani women are very competent but their cultural restrictions like Hijab (Pardah), lack of access toward socialization factor pushing back from other countries women entrepreneurs. Tominc and Rebernik (2003 : 781) included that women entrepreneurs in European countries contributed toward 28-33 percent of the businesses but the situation is worse in Pakistan due to the gender discrimination factors; females are not allowed to go outside because they have work-family conflict issues.Wees and Romijn (1987) stated that Pakistani women are facing gender discrimination due to men non-professional attitudes. The World Bank Country Sex Profile of Pakistan condemns the way that the status of ladies in Pakistan is among the least in the world. UNDP (1996) depicts the solid "inside/outside" division in Pakistan, where ladies are limited to "within" space of home and family, typified in the convention of veiling. This confines ladies' entrance to instruction, business, preparing openings and social services. Samina (1997) highlights another critical viewpoint by expressing that the social objection to ladies working outside the home converts into the intangibility of ladies in the work compel. Despite the fact that they take an interest effectively in the family and ranch undertakings, their unpaid work is seen as a social obligation instead of a monetary contribution. Boashan, Wang, and Dong (2009) on sex has regretted the poor markers of Pakistan contrasted and other creating openings and 
social services. In Europe, the movement rate of ladies in the work showcase has expanded in the most recent two decades. In Denmark it is 46.9 for every penny. In the Netherlands it expanded from 24.2 for each penny in 1975 to 40.6 for each penny in 1993. In the USA and Canada it developed from 37 for every penny and 32 for each penny individually in 1970 to 45 for every penny in 1990. In Pakistan it only expanded from 6.6 for every penny in 1968/69 to 13.6 for every penny in 1996/97 (Goheer 2003).

\section{Motivational Factors}

Motivation is considered as a strong element on entrepreneur's success in many developed countries. There are many studies being conducted to find out and elaborate the relationship of motivation and entrepreneurs. Szycher (2014) conducted a study to determine the motivational factors that lead to business success. Four main categories of entrepreneurial motivation were being illustrated by these studies. These categories included extrinsic reward, independence, intrinsic reward and family security. As per the study these factors compel the motivation level of entrepreneurs which in turn causes success of their business. One of the studies was conducted in United States by Mori and Fulgence (2009) focusing on nascent entrepreneurs. The findings highlighted that cause for opting self-employment were the same across the race but the motivation behind the new venture was different between races. Another study conducted by Lavelle and Al Sheikh (2013) that showed that self-employed people were more satisfied with their job and life in comparison with employees.

\section{Push or Pull Motivational Factors for Women Entrepreneurs}

The available literature on motivational factors falls into two main categories, i. e. push and pull (Vollmann 2008). A pull factor is considered an internal factor which includes desire of independent, accomplishment and desire of having authority (Shank 2002). Kostetska and Berezyak (2014) emphasized that the importance of finding out the motivational factors for women to opt for self-employment. These factors may provide a foundation for policy makers to assist women entrepreneurs to grow their businesses. Push factors are defined as negative aspects by Key (997) as unemployment and retrenchment that may force people to become entrepreneurs for their survival. Therefore in the view of literature it can be hypothesized that:

H1: Motivation plays a significant role in success of women entrepreneurial endeavors.

\section{Personality Traits}

The concept of personality trait has gained popularity among many other scholars (Greenhalgh et al. 2004). Some of our risk taking, locus of control and ambition one ((Lumpkin 2006)). Internal locus of control as an entrepreneurial personality trait has gained importance in research; Thomas and Mueller (2000) argue that there is a close connection between internal locus and entrepreneurial behavior. Boashan, Wang, and Dong (2009) argue that people who possess internal control prefer to be an entrepreneur. Entrepreneurship is illustrated as the risk taking activity and only be taken by those who has the nature of risk taking as they pick opportunity from the vision (Bruce 2012). One of the studies done on the subject was conducted by Key (1997) concluded that some of the personality traits including risk taking or risk tolerance, control and ambition are directly linked with entrepreneurial success. So this study assume that

H2: Certain Personality traits play a significant role in success of women entrepreneurial endeavors.

\section{Creativity}

The philosophical connection between creativity and entrepreneurship was initiated from different views and fields for instance from psychology (Zietsma 2011). Matherly and Goldsmith (2006) perceive creativity as the improvement system in the entrepreneurial aspect and has positive link with the success of business. Previous literature argues for a need of combining creative thinking and systematic analysis for entrepreneurial success. They said that entrepreneurs may possess ability to notice recognize and avail opportunities that other may perceive as problems. William (2011) puts creativity as one of the leading factors essential for women entrepreneurs and can compete them with male business holders. In the light of above support it can be hypothesized that: 
H3: Creativity plays a significant role in success of women entrepreneurial endeavors.

\section{Access to Finance}

Though women entrepreneurs play a vital role in the overall economic development as well as in their families, there is a general concept that women entrepreneurs show low business progress in comparison to their male counterparts (Akanji 2011). Access to finance is a critical aspect of women that hinders their ability to start their own business. Many authors including Key (1997) and Boashan, Wang, and Dong (2009) revealed that generally banks largely discriminate against women. While the banks in response justify by claiming that this discrimination is due to the profile of the entrepreneurs, however this idea is agreed upon by literature. This reasoning also justifies the study conducted by Bruce (2012) about the women inclination to start their business venture with their own savings or borrowing money from their close circle. So, it is supposed that

H4: Access to finance plays a significant role in success of women entrepreneurial endeavors.

\section{Relationship between Motivation and Family Factors}

Motivation is highly affected by family support in fact many studies support that the family support is the only factor that gives the inspiration to women specially as they are considered as less socialize in society than male community in Pakistan (Shapiro 2013 and Smith 1984). So the level of motivation will be higher if female satisfy from their home and they have family encouragement (Bosma, Van Stel, and Suddle 2012). With the help of prior studies it can be assumed that

$\mathrm{H} 5$ : Motivation has positive relationship with family factors.

\section{Relationship between Personality Trait and Family Factors}

Salarzehi, Armesh, and Nikbin (2010) explain the relationship as gender trait comes from the personality of the family, what the gender actually act basically reflects the cultural value of the family. Magrabi (2012) argues that family environment actually made the child personality and female are more close to home activities so their personality actually reflects what the honor of house told them; female will be more creative and confident in personality if they are given the right to express their thought and feelings in day to day matters. So it can be concluded

H6: Personality trait has positive relationship with family factors.

H7: Creativity has positive relationship with family factors.

\section{Relationship between Access to Finance and Family Factors}

Guillén (2013) stated that female usually gain access to finance through their close circle friends but if they supposed to be encouraged by their parents, than they will be more capable to personally contact to different loan schemes or they don't need to be limited in their idea due to financial hindrances. So with the limited literature on the relationship this study tries to shed some light on this limited relation through hypothesizing H8: Access to finance has positive relationship with family factors

\section{Mediating Role of Family Factors with Success of Women Entrepreneurial Endeavors}

Family of women entrepreneur has effects on business creation and progress. Family support and cooperation toward entrepreneurs is essential for entrepreneurial success (Guillén 2013). One of the understandings about the women entrepreneurs is that women are more inclined to opt to be entrepreneurs if their spouses are running businesses (Gorchels 2012). A study revealed that positive attitude of parents and husbands of women is positively related to women participation in higher education which supporting a women to participate in entrepreneurial activities and it is highly mediating factor for women entrepreneurs. Females belonging 
to entrepreneurial families, either having one or both parents, are most likely very confident in opting for entrepreneurial career (Mordi 2010). So this study hypothesizes that

H9: Family support plays a positive mediation role in the success of women entrepreneurial endeavors.

\section{Success of Entrepreneurial Ventures}

The concept of entrepreneurial success is being defined in different aspects, the simplest definition emphasized on the revenue generation from the venture, profit generation, ventures survival and yield (Carter and Evans 2012). Measuring the successful factors of entrepreneurial venture is still controversial because there is no agreeable dimensions of measuring success. For the purpose of present study the criteria of success for entrepreneurial ventures is generated from the general definition of many researchers as business has been operationalized for at least 3 years (Ebrashi 2013 and Watson and Wilson 2010). Hence the objective of present study is to explore the factors that lead the success of women entrepreneurial business venture.

With the help of literature support the research framework is drawn (see Figure 1).

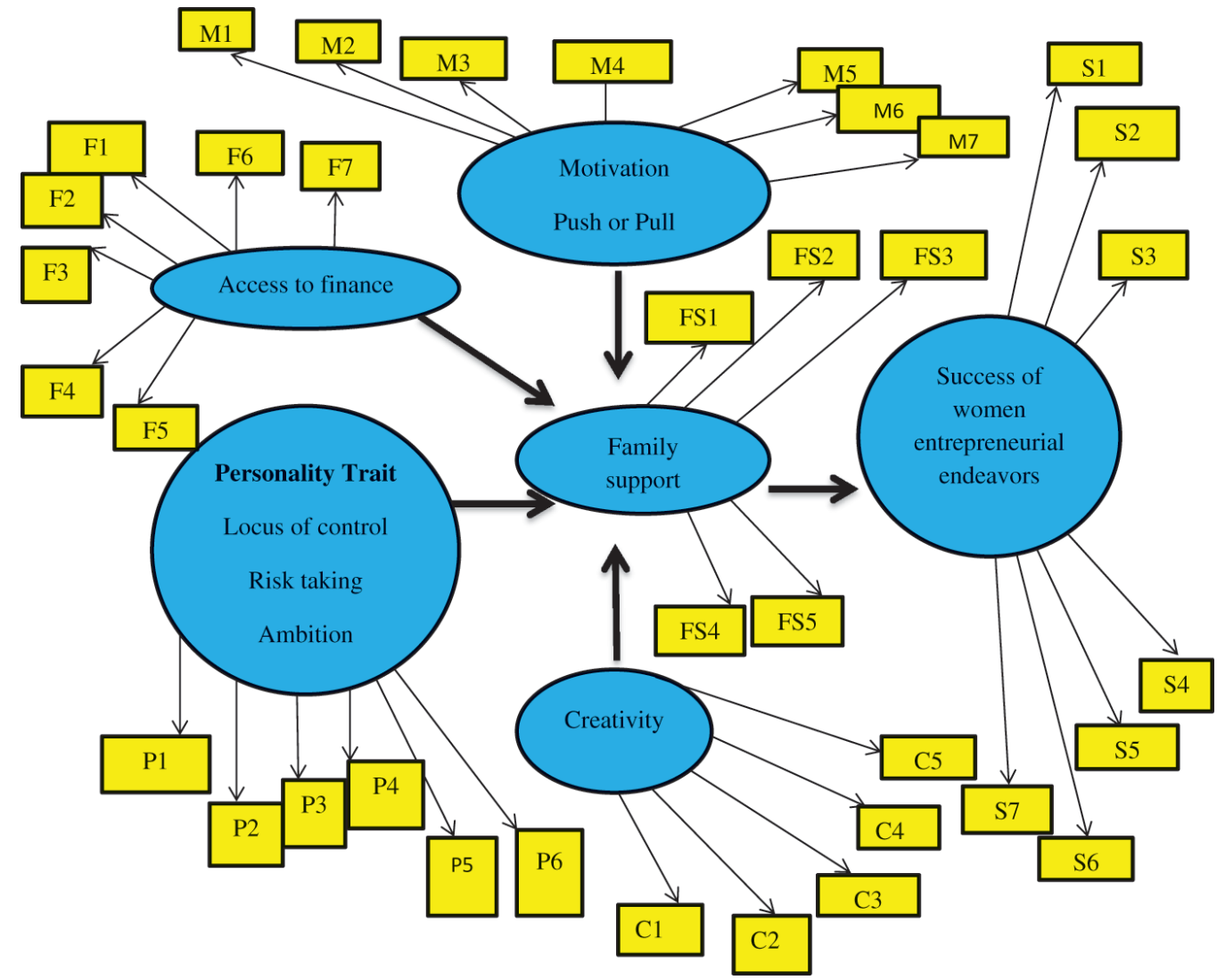

Figure 1: Research framework.

\section{Methodology}

Data were collected from the women who are running businesses from last 3 years through purposive sampling (Martyn 2011). A total of 200 questionnaires were used out of which 190 were useful. Respondent were given a surety of confidentiality. To ensure the reliability and validity of the construct and questionnaire pilot study was done which fulfill the acceptable limit of 0.4 and above for indicator reliability and 0.5 and above for validity (Hair et al. 2010). Reliability of the main study assessed through "indicator reliability" and "internal consistency reliability". The "indicator reliability" reflects that whether the each construct of the main variable accurately measure the true phenomenon of research and its value should be 0.4 or above (Hair et al. 2011). Sekaran and Bougie (2010) defines internal consistency as Composite reliability value, each variable should differently measuring the point of interest they should not be correlated and its value must be 0.7 (see Table 2). For Validity 
the two main criteria given by Hair et al. (2011) and Ringle, Wende, and Becker (2014) through "convergent" and "discriminant validity" was fulfilled by main study data (see Table 2).

Table 1: Factor Analysis.

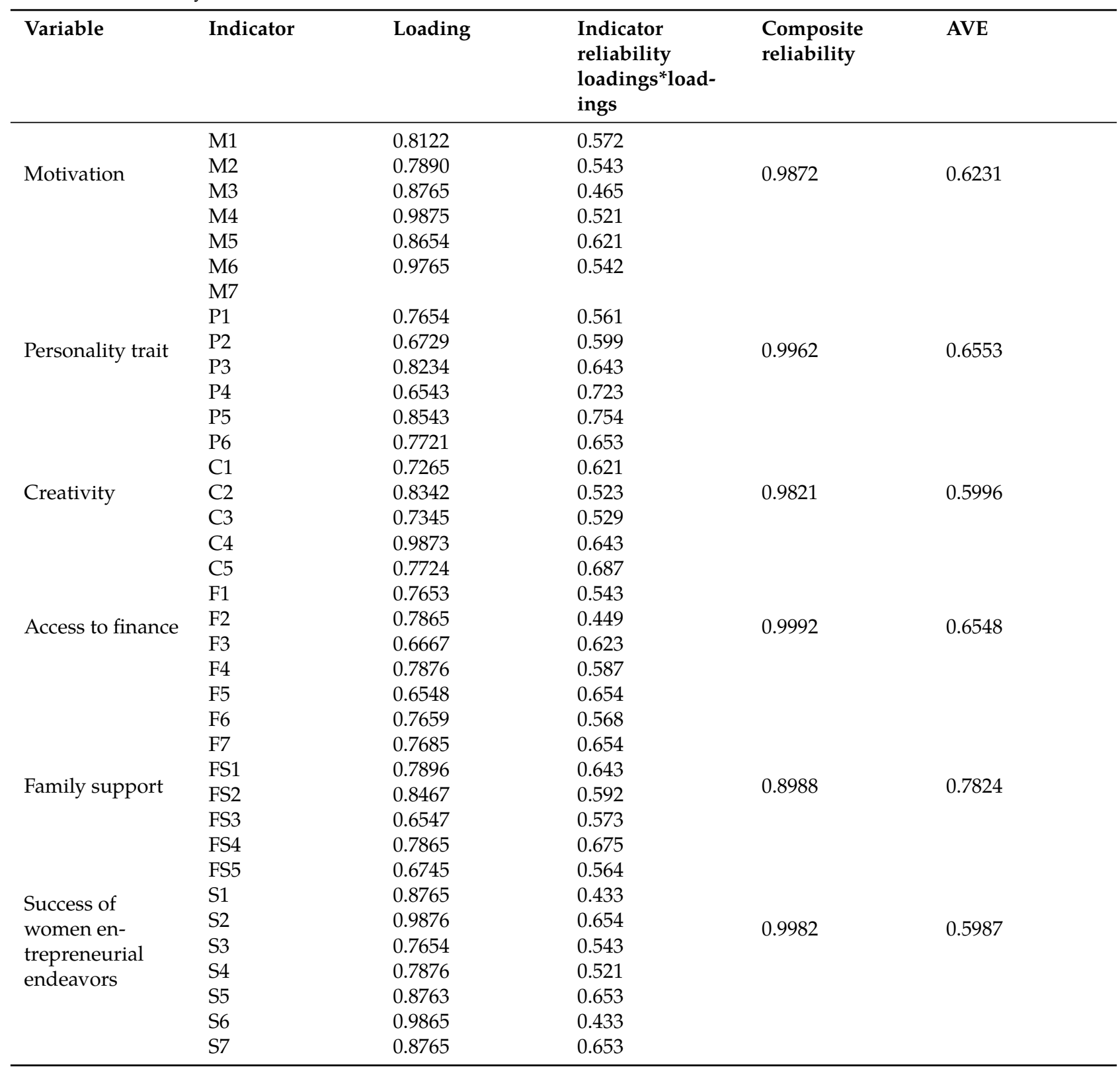

Table 2: AVEAU.

\begin{tabular}{|c|c|c|c|c|c|c|c|}
\hline \multicolumn{8}{|l|}{$\begin{array}{l}\text { AVE versus } \\
\text { correl }\end{array}$} \\
\hline Motivation & 1.0000 & & & & & & \\
\hline $\begin{array}{l}\text { Personality } \\
\text { trait }\end{array}$ & 0.1142 & 1.0000 & & & & & \\
\hline Creativity & 0.1452 & 0.2412 & 1.0000 & & & & \\
\hline $\begin{array}{l}\text { Access to } \\
\text { finance }\end{array}$ & 0.1764 & 0.5436 & 0.8721 & 1.0000 & & & \\
\hline $\begin{array}{l}\text { Family } \\
\text { support }\end{array}$ & 0.1563 & 0.8763 & 0.5986 & 0.8764 & 1.0000 & & \\
\hline $\begin{array}{l}\text { Women en- } \\
\text { trepreneurial } \\
\text { success }\end{array}$ & 0.3242 & 0.6754 & & 0.8864 & 0.9876 & 9876 & 1.0000 \\
\hline
\end{tabular}


Sekaran and Bougie (2010)Sekaran and Bougie (2010) explain convergent validity can be assessed through the value of "average variance extracted (AVE)" and if its value lies above 0.5 then it does confirm the validity aspect. Similarly, correlational value among other variables must be less than the value of AVE square where it confirms the complete aspect of Divergent validity (Ringle, Wende, and Becker 2014).

\section{Coodness of Fit}

In order to test the proposed research model through goodness of fit (Fornell and Larcker 1987) the model was broken in to two aspects; one of which was without mediator named as 1a and one along with mediator named as $1 \mathrm{~b}$. The $1 \mathrm{a}$ model shows that $59 \%$ of variance is being explained by the antecedent of success of women entrepreneurial endeavor including motivation, personality trait, creativity and access to finance (see Figure 2). When the goodness of fit or R2 for the model $1 \mathrm{~b}$ was assessed than it confirms that with adding the mediating role of family support the antecedent are explaining $69 \%$ of variance in the dependent variable (women entrepreneurial endeavor success) (see Figure 3).

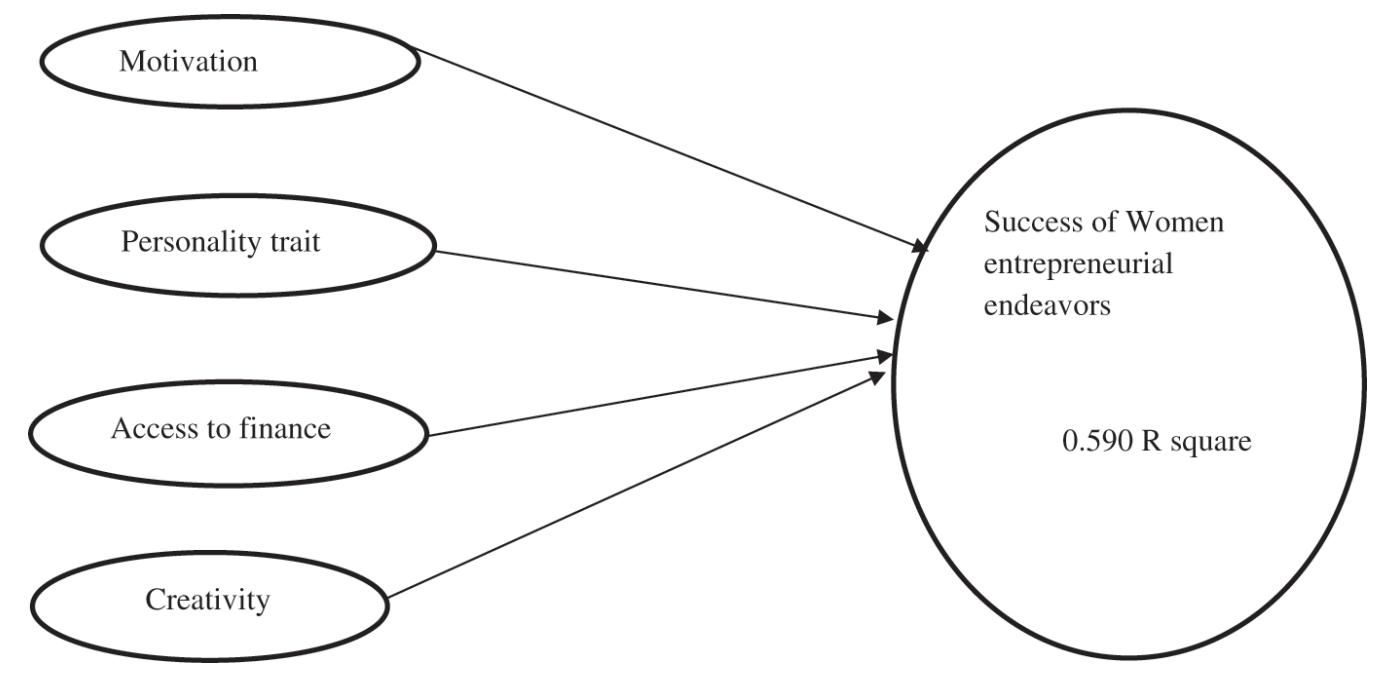

Figure 2: Research model.

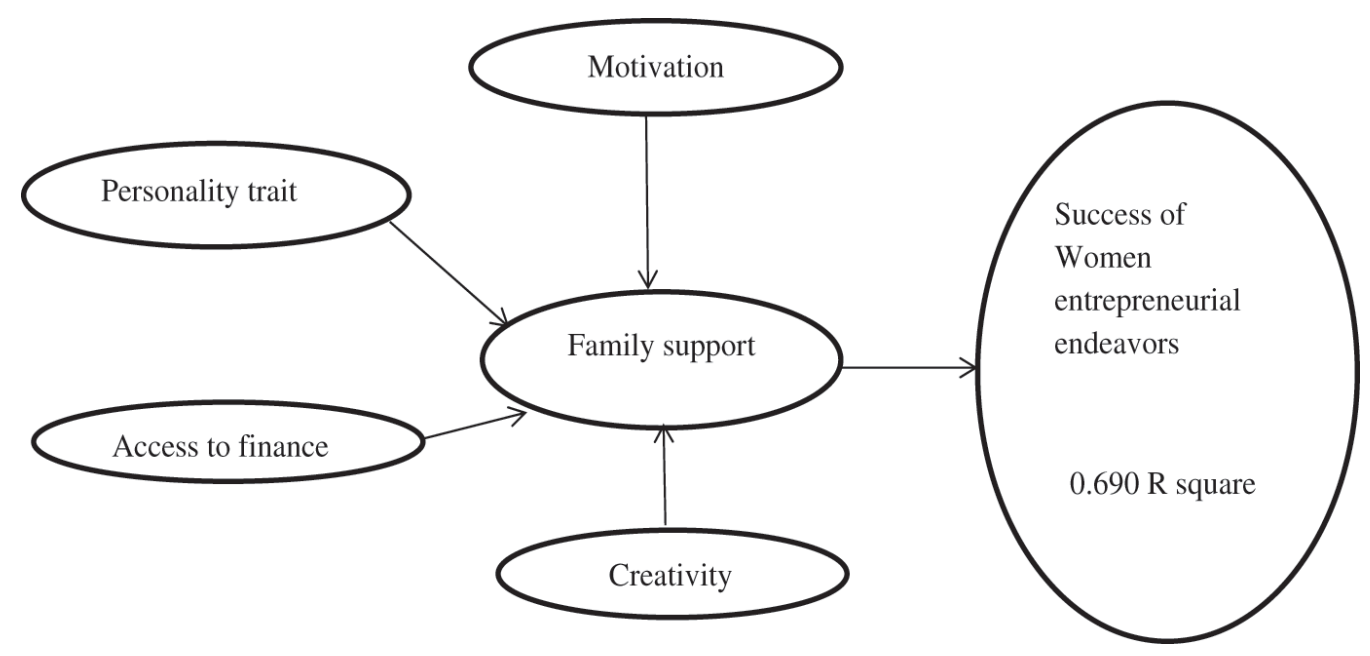

Figure 3: Direct relation.

\section{Mediation Analysis}

In PLS Hair et al. (2011) presented the mediation analysis through variance accounted for value but before applying VAF, it is essential to make sure that direct (without mediator see Figure 2) and indirect relationship (see Figure 3) are significant. If the value of VAF (P12 • P23) /(P12 • P23 +P13) lies 60-80 than it accounts for full 
mediation and value within 20-59 shows partial mediation (Fornell and Larcker 1987; Hair et al. 2010). Figure 4 shows that in proposed research model the role of family support account for the partial mediation as the value comes $43 \%$. This explains that if women find family support than they will be more in number to start their own businesses (Hair et al. 2011).

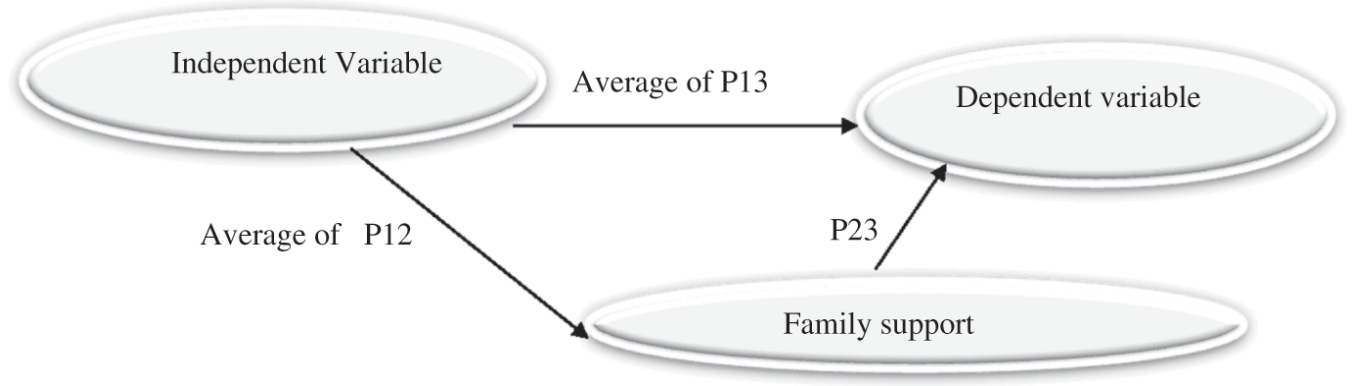

Figure 4: Mediation effect.

\section{Discussion}

Motivation was the most significant factor in the success of women entrepreneurial endeavors. The result gained from this research is in accordance with the previous on the same topic, those researchers who tried to develop the relation between motivation and success of entrepreneurial endeavors like Gorchels (2012), Guillén (2013), Hany (2011), and Hasna (2007). The beta value of the results shows that among all direct relationships the motivation has more strength in changing the success of women entrepreneurial success; a unit change in motivation will bring 0.290 times change in the success of female businesses (see Table 3).

Table 3: Hypothesis testing.

\begin{tabular}{|c|c|c|c|c|}
\hline $\begin{array}{l}\text { Hypoth- } \\
\text { esis }\end{array}$ & Relationship & Beta & $\begin{array}{l}\text { Significance } \\
\text { value }\end{array}$ & $\mathbf{S} / \mathbf{R}$ \\
\hline $\mathrm{H} 1$ & Motivation $\rightarrow$ Success of women e. Endeavors. & 0.290 & 2.4564 & S \\
\hline $\mathrm{H} 2$ & Personality trait $\rightarrow$ Success of women e. Endeavors. & 0.162 & 2.4653 & S \\
\hline $\mathrm{H} 3$ & Creativity $\rightarrow$ Success of women e. Endeavors & 0.216 & 1.9976 & S \\
\hline $\mathrm{H} 4$ & Access to finance $\rightarrow$ Success of women e. Endeavors & 0.172 & 2.8765 & S \\
\hline H5 & Motivation $\rightarrow$ Family support & 0.395 & 3.3586 & S \\
\hline H6 & Personality trait $\rightarrow$ Family support & 0.192 & 2.8973 & S \\
\hline H7 & Creativity $\rightarrow$ Family support & 0.298 & 2.9999 & S \\
\hline H8 & Access to finance $\rightarrow$ Family support & 0.182 & 3.8976 & $\mathrm{~S}$ \\
\hline $\mathrm{H} 9$ & Family support $\rightarrow$ Success of women e. Endeavors & -0.590 & 3.2453 & $S$ \\
\hline
\end{tabular}

Personality trait had significant impact on the success of women business endeavors. The result indicates the acceptance of current study hypothesis with the beta and $t$ value of $0.162,2.4653$ indicate that by changing personality trait it will bring 0.162 times improvement in the success of female entrepreneurial endeavors (see Table 3). This is also in line with the results reported by Shank (2002) and Richi (2011).

Creativity has found as a second important factor in bringing change associated with the female business startup. The respondents of the study agree that they are strongly inspired by creativity factor as the beta value indicates the evidence (see Table 3). These results are also strengthening the role of creativity as a factor in business startups as supported by many others (Magrabi 2012; Salarzehi, Armesh, and Nikbin 2010; Shapiro 2013).

Access to finance had been an important topic of research for long and this study also confirms its positive and significant role for the female as highlighted by Lamontagne (2014) and Porter and Kramer (2011). Interesting fact that this study brings for the literature is that all the antecedents (motivation, personality trait, creativity, access to finance) that are considered to be essential for the women success are highly associated with the family support that in turn give support to the research hypothesis (see Table 3). As table shows that beta values goes up in the H5-H8. But the negative value of beta for family factors and women entrepreneurial success (H9) shows that the respondents were disagree on the role of family in starting their businesses as confirm by the literature that there are two types of views on this aspect; one is that women started their businesses who didn't get family support but involve in business activities to show them they can do each and every thing 
and such type of behavior was found from the respondent of the study (Shapiro 2013). Other is those female who got full family support and involve in business activities (Szycher 2014). As for the matter of this study, the concern is that data was collected from the less developed economy and majority of the respondents were belonged to those family background that didn't get enough support from their families but they agreed (confirm through thet value of 3.2453, H9) on the thought that if all the families become very supportive to their female family members then majority of women will involve in the business activity as it gives more flexibility to maintain a balance between work and at home. The mediation analysis of the family support has been confirmed through this study as without family support the proposed model able to explain $59 \%$ of the variance in the success of women entrepreneurial success but with the family support as the mediator the model boosted up to $69 \%$ of variance being explained by this mediating role. As for as how much mediation role the family support can play was assessed through Hair et al. (2010) criteria that showed family support partially mediated the relationship between antecedent of success (motivation, personality trait, creativity, access to finance) and success of women entrepreneurial endeavors. These results are in line with the results of Thompson (2002) and Seelos and Mair (2004).

This study highlights the factors that cause the female of underdeveloped country to start their own business with the new insight of mediating role of family support. So the labor ministry as well as the social worker can take new insight from this paper; in order to increase the ratio of female to male labor in the global market. There is strong need to remove the gender discrimination thought that can be possibly eliminated through different television channels and other social media and government should take initiative to secure the participation of female involvement in the job creation activities through providing easy access to finance and by making the economy free from gender biasness.

\section{Conclusion}

Findings of this study conclude that success factors for female entrepreneurial endeavors are motivation, personality trait, creativity, access to finance through mediating role of family factors. These factors have a positive correlation with the success of women entrepreneurial endeavors. However, the family factors seem having both views as far as for the women entrepreneur is concerned. Some of the policy measure regarding access to credit should be taken by government to deal with the worse situation of women entrepreneur in Pakistan through arranging small loans from zakat funds. The author of the paper recommends some strategic policy measures for government in order to eradicate the problems of Pakistani women entrepreneurs:

- It is proposed that workshop should be held to disseminate the information on the "Women ideas about business" through discussing the recommendations from the stakeholders.

- Almost no hard data are obtainable on women entrepreneurs in Pakistan. Government divisions and the business associations/networking organizations have no information on the total number of women entrepreneurs, their lines of business, value added, employment or related information. Different endeavors have been made by associations, for example, EPB and FWBL to create information sets, yet the outcomes are a long way from tasteful and the data is not routinely overhauled. It is in this way suggested an exhaustive database of ladies business visionaries in Pakistan ought to be arranged and utilized as a part of future research and activity arranges.

- There are a small number of federal and provincial institutions working specifically for the development of SMEs. Unfortunately, do not reach out to women entrepreneurs; their operations are normally targeted at businessmen as business is usually considered a male domain in Pakistan. It is proposed that one such institution should be selected for a gender audit of its operations. SMEDA, a federal institution devoted to providing enterprise development services, might be a suitable candidate. The gender audit would identify gaps and distortions in existing services that could be rectified in future operations.

- A comprehensive module on entrepreneurship could be developed and introduced in the Master's courses at the First Women's University, Rawalpindi as a pilot project. This course could subsequently be extended to other institutions and even run by SME development institutions.

\section{Acknowledgment}

The author of this paper is highly thankful to T. Ramayah for his kind assistance. 


\section{References}

Abdullah, A. 2012. "The effect of entrepreneurial orientation on the organizational performance: A study on the Islamic banks in Yemen using the partial least squares approach." Arabian Journal of Business and Management Review (Oman Chapter) 2 (1): 73.

Adetu, S. 2014. “AIESEC Pursues Social Entrepreneurship for Economic Development." Spygahna. September 262014. http://www.spyghana.com/aiesec-pursues-social-entrepreneurship-economic-development.

Afza, T., M. Hassan, and M.A. Rashid. 2010. “Enterprising Behavior of Enterprise-Less Rural Women Entrepreneurs of Khyber Pakhtunkhawa of Pakistan." European Journal of Social Sciences 18 (1): 109-119.

Akanji, O.O. 2011. "Microfinance in Empowering Women in Africa." from The African Executive Magazine:. January 112014.

AlMunajjed, M. 2013. "Young Entrepreneurs: Engine for CCC Growth and Prosperity.". September 282 014. http://www.arabnews.com/economy/young-entrepreneurs-engine-gcc-growth-and-prosperity.

Alsahlawi, M. 2011. "Social Entrepreneurship in the Middle East with More Emphasis on the Gulf Region." Proceedings on the 6th European conference on Innovation and Entrepreneurship, 14th-16th September 2011, p.1.

Audretsch, D.B., M. Keilbach, and E. Lehmann. 2006. Entrepreneurship and Economic Growth. Oxford: Oxford University Press.

Barringer, B., and D. Ireland. 2011. Entrepreneurship: Successfully Launching New Ventures. New Jersey: Prentice Hall.

Begum, H. 2011. Service Innovation in Small and Medium Enterprises in Singapore. Singapore: Singapore Management University.

Blanch, D.E. 2011. “Coping with Entrepreneurial Stress as Motivational Factor.” Harvard Business Review (March/April): 48-64.

Boashan, M., K. Wang, and T. Dong. 2009. "Self-Employed Women and Their F Families: Time Use Socio-Economic Characteristics." Journal of Small Business Management 25 (3): 30-37.

Boerboom, P.A.L. 2010. “Must Success Cost so Much?” Harvard Business Review (March/April): 137-148.

Bornstein, D. 2012. How to Change the World. Oxford: Oxford University Press.

Bosma, N., A. Van Stel, and K. Suddle. 2012. “The Geography of New Firm Formation: Evidence from Subsidiaries in the Netherlands." International Entrepreneurship and Management Journal 4 (2): 129-146.

Bruce, W. 2012. Role of Family Factors in Women Success Entrepreneurship. Singapore: McGraw-Hill Higher Education.

Carter, S., and D.J. Evans. 2012. Enterprise and Small Business, Principles, Practice and Policy. Great Britain: Pearson Education.

Charantimath, P.M. 2005. “Entrepreneurship Development and Small Business Enterprises. Pearson India.", http://academic.safaribooksonline.com/book/international-business-globalization/9789332510470.

Chitsike, C. 2000. “Culture as a Barrier to Rural Women's Entrepreneurship: Experience from Zimbabwe." Gender \& Development; 8 (1): 71-77.

Ministry of Labour, Manpower and Overseas Pakistanis. 2013. Draft Labor Policy of the Covernment of Pakistan Islamabad: Covernment of Pakistan.

Ebrashi, R.E. 2013. “Social Entrepreneurship Theory and Sustainable Social Impact.” Social Responsibility Journal 9 (2): 188-209. DOI:http://dx.doi.org/10.1108/SRJ-07-2011-0013.

Fornell, C., and D.F. Larcker. 1987. “Evaluating Structural Equation Models with Unobservable Variables and Measurement Error.” Journal of Marketing Research 18 (1): 39-50.

Goheer, N.A. 2003. Women Entrepreneurs in Pakistan. International Labour Organization.

Gorchels, L. 2012. Business Model Renewal: How to Grow and Prosper by Defying Best Practices and Reinventing Your Strategy. Singapore: McGrawHillMay 19 2015. http://academic.safaribooksonline.com/book/strategy-business-planning/9780071784030.

Greenhalgh, T., G. Robert, F. Macfarlane, P. Bate, and O. Kyriakidou. 2004. "Diffusion of Innovations in Service Organizations: Systematic Review and Recommendations." The Milbank Quarterly 82: 607-610.

Greenhill, J.H. 2011. “Entrepreneurship in Developing Countries.” Academy of Management Review 10 (1): 76-88.

Guillén, M.F. 2013. Women Entrepreneurs. New York and London: RoutledgeApril 01 2015. http://academic.safaribooksonline.com/book/smallbusiness-andentrepreneurship/9780415523479.

Hair, J.F., W.C. Black, B.J. Babin, and R.E. Anderson. 2010. Multivariate Data Analysis. Upper Saddle River: Prentice-Hall.

Hair, J.F., G.T.M. Hult, C.M. Ringle, and M. Sarstedt. 2011. A Primer on Partial Least Squares Structural Equation Modeling (PLS-SEM). Los Angeles: Sage Publication.

Hany, H.M. 2011. “Social Entrepreneurship: Cenerating Solutions to Global Challenges." International Journal of Management Information System 15 (1): 1-19.

Hasna, A.M. 2007. “Dimensions of Sustainability." Journal of Engineering for Sustainable Development: Energy, Environment, and Health 2 (1): 47-57. DOI:10.3992/2166-2517-1.2.47.

Kavanagh, C., O. Murphy, and O. Dwyer. 2012. "Education is Key to Fostering Entrepreneurial Spirit.". July 15 2014. http://www.irishexaminer.com/business/education-is-key-to-fostering-entrepreneurial-spirit212911.html.

Key, J. 1997. Research Design in Occupational Education. Oklahoma State University, http://www.okstate.edu/ag/agedcm4h/academic/aged5980a/5980/newpage110.html.

Kostetska, I., and I. Berezyak. 2014. "Social Entrepreneurship as an Innovative Solution Mechanism of Social Problems of Society." Management Theory \& Studies for Rural Business \& Infrastructure Development 36 (2/3): 569-577.

Lamontagne, C. 2014. "Entrepreneurship on the Rise in Saudi Arabia.", http://www.gew.co/blog/entrepreneurship-in-saudi-arabia.

Lavelle, K., and H. Al Sheikh. 2013. Civing Voice to Women Entrepreneurs. Women's Entrepreneurship Initiative in Collaboration with Ashridge Business School in Saudi Arabia. Women's Entrepreneurship Initiative Ltd.

Lumpkin, A. Dess. 2006. “Microfinance, Rural Livelihood, and Women's Empowerment in Uganda." African Studies Center Research Report. August 32009.

Magrabi, N. 2012. "Mosaic." Recognizing extra ordinary women, https://mosaicofmuslimwomen.wordpress.com/2012/02/08/norah-magraby.

Makhlouf, H.H. 2011. "Social Entrepreneurship: Cenerating Solutions to Global Challenges." International Journal of Management and Information Systems 15 (1): 1-8.

Martyn, D. 2011. The Good Research Guide for Small-Scale Social Research Projects., 15. Buckingham: Open University Press. 
Matherly, T., and R. Coldsmit. 2006. “The Two Faces of Creativity." Business Horizons 28, (5): 8.

Mordi, G. 2010. "Family Factors as the Essential Element of Society Success." Journal of Business Venturing 9 (10): 111-167.

Mori, N., and K. Fulgence. (2009). Social Entrepreneurship in Tanzania: Assessment of Enabling Environment. 2nd EMES International Conference on Social Enterprise, Trento Italy. July 1-4 2009.

Porter, M., and M. Kramer. 2011. “How to Fix Capitalism?” Business Harvard Review 4: 113-209.

Richi, O. 2011. US-Saudi Women's Forum on Social Entrepreneurship. Saudia: Saudi printing press.

Ringle, C.M., S. Wende, and J.-M. Becker. 2014. "Smartpls 3.", www.smartpls.com.

Salarzehi, H., H. Armesh, and D. Nikbin. 2010. "Waqf as a Social Entrepreneurship Model in Islam." International Journal of Business and Management 5 (7): 179-186.

Samina, K. 1997. “South Asia Poverty Alleviation Program UNDP.” 114. Women Empowerment and Poverty Alleviation in South Asia: The Dual benefits of Microcredit.

Seelos, C., and ]. Mair. 2004. Social Entrepreneurship: Creating New Business Models to Serve the Poor. Bloomington: Kelley School of Business, Indiana University.

Sekaran, U., and R. Bougie. 2010. Research Methods for Business: A Skill Building Approach. New Jersey: Wiley.

Shank, G. 2002. Qualitative Research. A Personal Skills Approach. New Jersey: Merrill Prentice Hall, http://wagner.nyu.edu/leadership/publications/files/Qualitative_Research.pdf.

Shapiro, R. 2013. Real Problem Solvers: Social Entrepreneurs in America. Palo Alto, CA, USA: Stanford University Press, http://www.ebrary.com.

Smith, M.J. 1984. “Contingency Rules Theory, Context, and Compliance Behaviors." Human Communication Research 10: 489-512.

Szycher, M. 2014. The Guide to Entrepreneurship. Boca Raton, Florida: CRC Press, http://academic.safaribooksonline.com/book/smallbusinessand-entrepreneurship/9781482209075.

Thomas, A.S., and S.L. Mueller. 2000. “A case for comparative entrepreneurship: Assessing the relevance of culture." Journal of International Business Studies 31 (2): 287-301.

Thompson, J.L. 2002. "The World of the Social Entrepreneur." The International Journal of Public Sector Management 15 (4/5): 413.

Tominc, P., and M. Rebernik. 2003. The Scarcity of Women Entrepreneurship. Slovenia: Razlogova University of Maribor, Faculty of economics and business.

UNDP. 1996. “Editorial: Responsible well-being—a personal agenda for development.” World development 25 (11): $1743-1754$.

Vollmann, M. 2008. “"Social Entrepreneurship in Cermany.” Social Science Research Network. doi.”, http://dx.s.org/10.2139/ssrn.1162734.

Watson, M., and B. Wilson. 2010. Women Entrepreneurs in Establishing and Expanding the Business. US: ILO.

Wees, C.V., and H. Romijn. 1987 Entrepreneurship and Small Enterprise Development.

William, C.M. 2011. Flash of Brilliance. Philadelphia: Perseus Books.

Zietsma, R. 2011. "Motivation, Success and Problems of Entrepreneurs in Venezuela." Journal of Management Policy and Practice 13 (1): 11-29. 